\title{
COMPOUND OSTEOSYNTHESIS IN THE THORACIC SPINE FOR TREATMENT OF VERTEBRAL METASTASES
}

\author{
TECHNICAL REPORT
}

\author{
T. GLEN PAIT*, IGOR DE CASTRO**, KENAN I. ARNAUTOVIC**, LUIS A. BORBA**
}

\begin{abstract}
Metastases to vertebrae often cause bone destruction leading to instability and neural compression. Anterior surgical approaches allow tumor resection and direct neural decompression. For patients with a short life expectancy, vertebral body replacement with methyl-methacrylate polymerized in situ can be used for load sharing in the axial plane. Screws hung from the rod into the corpectomy site are incorporated into the acrylic cement. The technique described in this article allows for immediate spinal stabilization and provides a protective environment for the neural elements. All the patients tolerated the procedure well and were able to ambulation without an orthoses.
\end{abstract}

KEYWORDS: vertebral body metastasis, methyl-methacrylate implant, pain relief.

\section{Osteosíntese composta na coluna torácica para o tratamento de metástases vertebrais: relato técnico}

RESUMO - Metástases para a coluna vertebral frequentemente causam destruição óssea gerando instabilidade e compressão neural. A abordagem cirúrgica permite ressecção tumoral ampla e descompressão direta do tecido nervoso. Para pacientes com expectativa de vida não muito prolongada, a substituição do corpo vertebral por polímero de metilmetacrilato pode ser utilizada, havendo distribuição adequada da carga axial sobre a coluna vertebral. A técnica descrita neste estudo permite que ocorra estabilização da coluna vertebral de forma imediata proporcionando um meio de proteção das estruturas neurais. Os pacientes toleraram bem esse procedimento e foram capazes de deambular sem auxilio de órteses.

PALAVRAS-CHAVE: metástase vertebral, implante de metilmetacrilato, dor.

Instability of the spine consequent to the invasion of primary tumor is a serious complication in cancer patients. Common primary tumors include lung, breast, prostate and renal cancer ${ }^{1}$. Casadei et al. reported that none of their 25 patients with pathologic fractures at the thoracolumbar spine due to vertebral metastases had stable lesions ${ }^{2}$. In these patients, pain is the most important symptom ${ }^{3}$. Such pain is often relentless. Patients note localized back pain and radicular pain. Pain often announces instability due to bony destruction ${ }^{4}$. Pain may also be related to the expansive nature of the tumor with periostal invasion ${ }^{1}$. These individuals have broken bones and any movement, even breathing, will elicit pain ${ }^{5}$. Although the chances of cure may be elusive in patients with vertebral metastases, surgeons should try to provide them with a better quality of life.After surgical procedures such as anterior vertebral body resection, reconstruction and stabilization of the spine, an improvement of pain and neurological dysfunction is frequently observed. We present a safe, easy and low cost technique that can be used in those patients providing a better quality of life.

Department of Neurosurgery, University of Arkansas for Medical Sciences: *MD, FACS; **MD. Aceite: 17-novembro-1999.

T. Glen Pait, MD - Department of Neurosurgery, University of Arkansas for Medical Sciences - 4301 West Markham / Slot 507 - Little Rock, Arkansas 77025-7199 - USA. FAX 15016867928. 


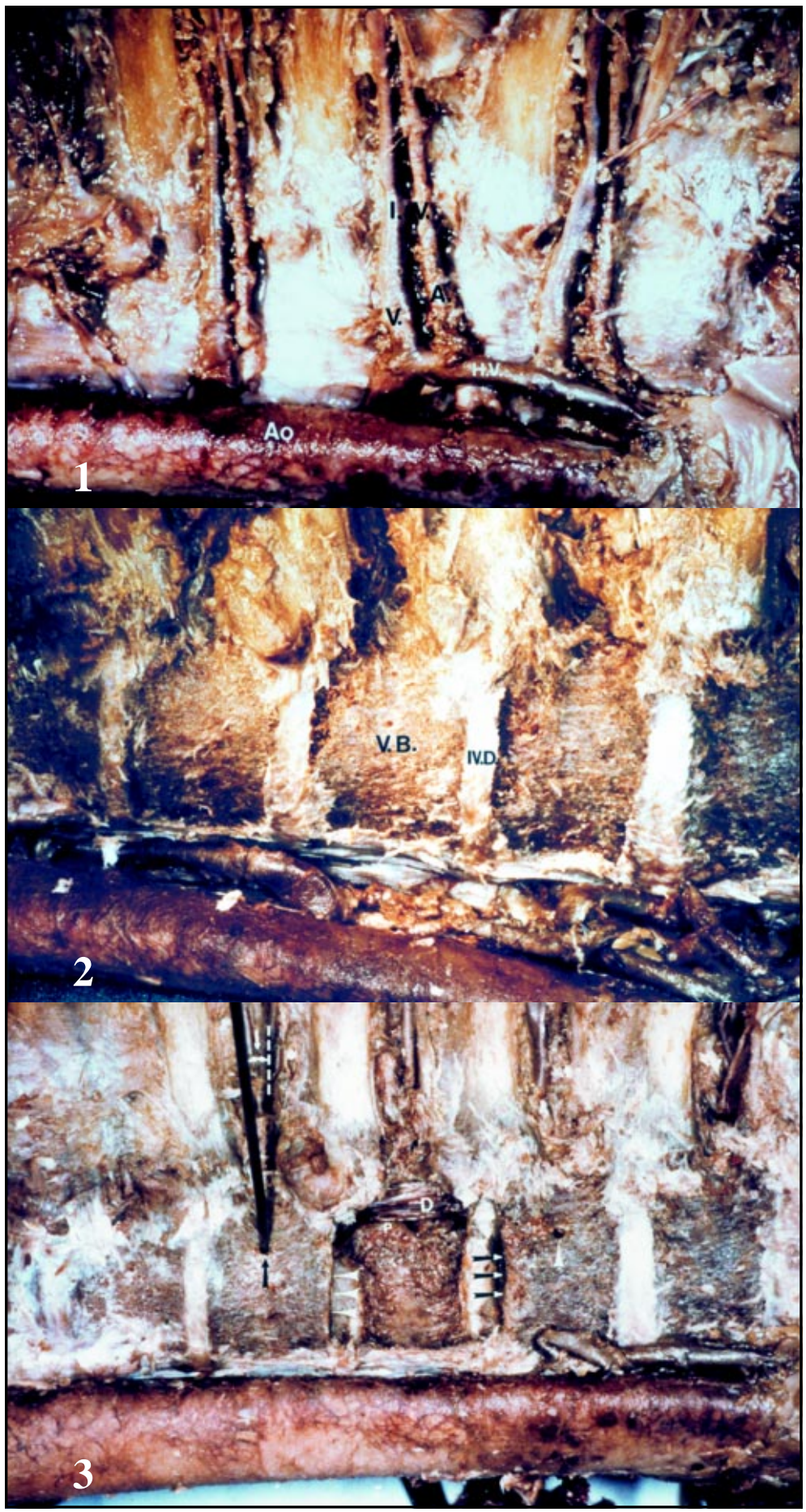

Figs 1-3.

Demonstration of the technique using a cadaver specimen. For details, see text. Ao, Aorta; H.V., Hemiazigos vein: I.V. $(A ; V)$, Intercostal vessels (artery; vein) IV.D., Intervertebral disc; IV.S. Intervertebral space; V.B., Vertebral body; $D$, Dura; P, Pedicle; $R, \operatorname{Rod}(T S R H$, Daneke, Menphis, $T N)$; $S$, $\operatorname{Screw}(s)$ (TSRH, Daneke, Menphis,TN.); M.R., Malleable retractor; P.C., Polymerizing cement (Aneuroplastic ${ }^{T M}$ Codman). 


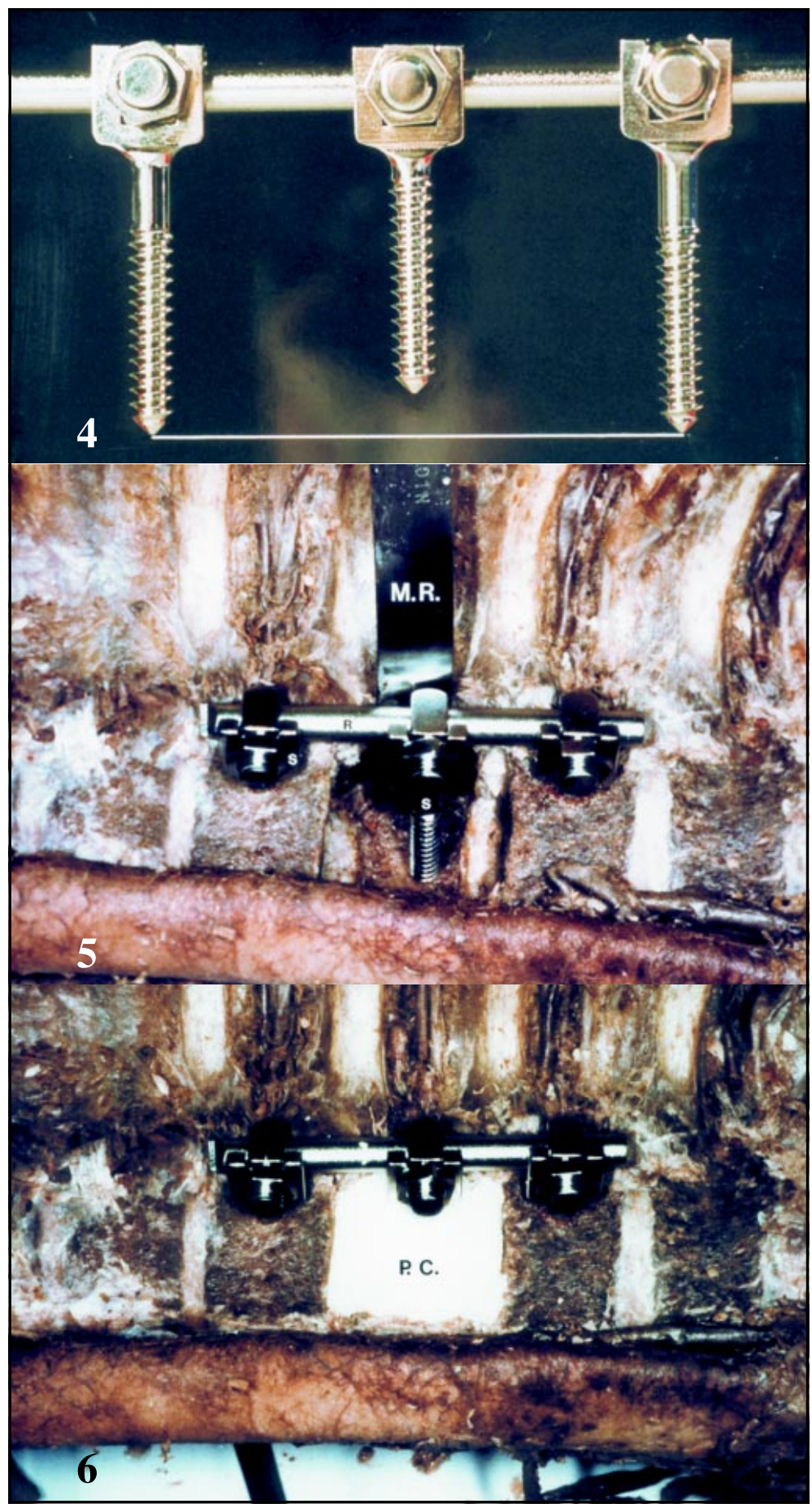

Figs 4-6

Demonstration of the technique using a cadaver specimen. For details, see text. Ao, Aorta; H.V., Hemiazigos vein, I.V. $(A ; V)$, Intercostal vessels (artery; vein); IV.D., Intervertebral disc; IV.S.

Intervertebral space, V.B., Vertebral body; $D$, Dura; P, Pedicle; $R, \operatorname{Rod}(T S R H$, Daneke, Menphis, $T N) ; S$, Screw $(s)$ (TSRH, Daneke, Menphis,TN.); M.R., Malleable retractor P.C., Polymerizing cement (Aneuroplastic ${ }^{T M}$ Codman). 


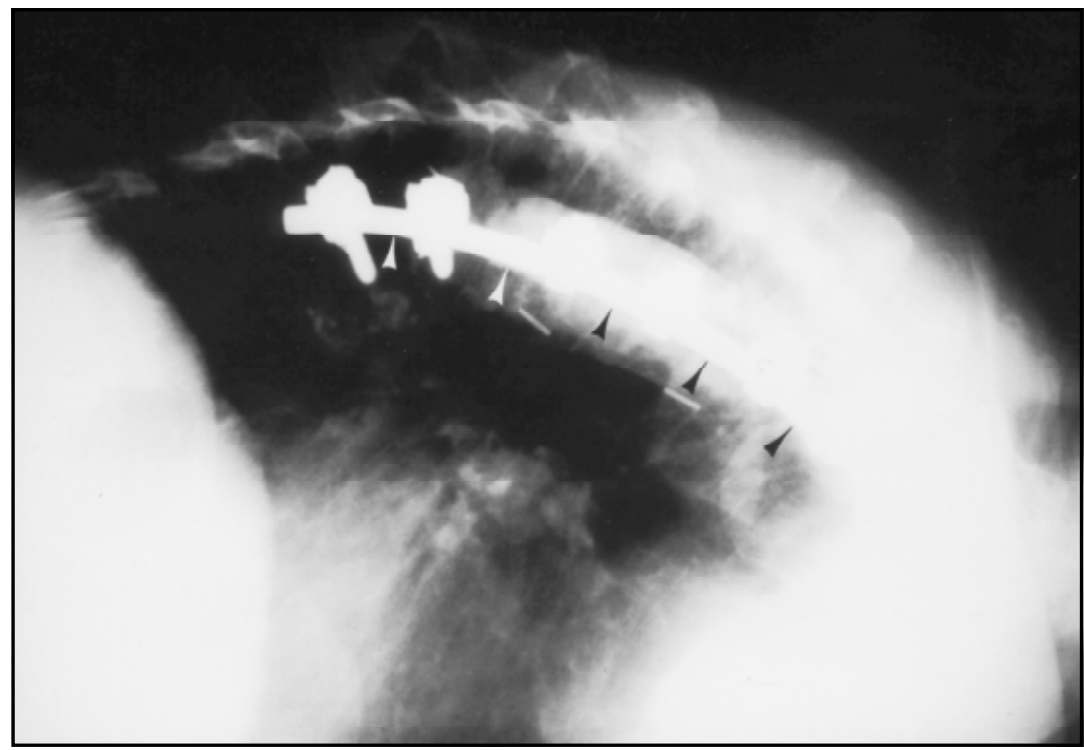

Fig 7. Postoperative X-ray of a patient.

\section{METHOD}

Six patients with metastatic lesions in the thoracic spine underwent anterior decompression of the spinal cord and stabilization. The operative technique involved debulking of the tumor and structurally inadequate bone. Neural decompression was confirmed by dural exposure and visualization of the opposite pedicle. Demonstration of the technique is summarized using a cadaver specimen (Figs 1-6).

The intercostal vessels course in the middle of the vertebral bodies. This anatomical relation is important to identify the intervertebral discs spaces and the vertebral body. (Fig 1). The intercostal vessels were removed and the interspaces and the vertebral body were easily identified(Fig 2). Discectomies were performed at one level above and below the lesion. The corpectomy was completed using osteotomies and a surgical drill (Midas $\left.\operatorname{Rex}^{\mathrm{TM}}\right)$. The dura was exposed. The decompression was not complete until the contralateral pedicle was exposed. The endplates of adjacent vertebrae were removed to promote acrylic fixation (Fig 3 white arrow head). An appropriate rod length was measured and cut. Screw fixation sites were determined; angled $10^{\circ}$ anteriorly to avoid neurovascular structures (Fig 3 small white arrow). The acrylic anchoring center screw was shorter than the cranial and the caudal bone fixation screws (Fig 4). The center screw was preloaded onto the rod before securing the rod onto the bone screws. The center screw now hangs into the corpectomy site.

\section{COMMENTS}

Although the duration of survival was limited, surgery proved to be beneficial in providing a significant and early improvement in the patients functional status and pain relief, bringing about an improvement in the quality of life $\mathrm{e}^{6,7}$. The mortality and functional failure with pain and neurological impairment occurrs when there was spreading of the tumor to the peri-vertebral soft tissues and with epiduritis extending beyond the bone lesion ${ }^{1,8}$. Thus, to be perfectly efficacious, anterior spine surgery for vertebral metastases should be integrated, in the global treatment of the metastatic disease.

Our experience and the results found in the literature suggest that transthoracic corpectomy and spinal stabilization can improve the quality of life considerably in cancer patients with spinal metastases by restoring or preserving ambulation and by controlling intractable spinal pain with acceptable rates of morbidity and mortality ${ }^{9}$. Indeed the quality of life was improved for these surgically treated patients. We recommend surgical decompression and stabilization for selected patients with vertebral metastases 


\section{REFERENCES}

1. Onimus M, Papin P, Gangloff S. Results of surgical treatment of spinal thoracic and lumbar metastases. Eur Spine J 1996;5:407-411.

2. Casadei R, Greggi T, Miglietta A, Perozzi M, Barchetti M, Parisini P. Posterior surgery for the treatment of thoracolumbar pathologic fractures in metastatic patient. Chirurg Organi Mov 1998;83:149-158.

3. Cappelletto B, Del Fabro P, Meo A. Decompression and surgical stabilization in the palliative treatment of vertebral metastases. Chirurg Organi Movi 1998;83:167-176.

4. Seiler H, Graf L, von Pawel-Rammingen U. Wirbelsaulenstabilisierung bei extraduraler. Metastasenkrankheit: Indikation und Verlauf bei 32 Patienten. Unfallchirurgie. 1997;100:294-300.

5. Taneichi H, Kaneda K, Takeda N, Abumi K, Stoh S. Risk factors and probability of vertebral body collapse in metastases of thoracic and lumbar spine. Spine 1997;22:239-245.

6. Okuyama T, Korenaga D, Tamura S, et al.. Quality of life following surgery for vertebral metastases from breast cancer. J Surg Oncol 1999;70:60-63.

7. Gallinaro P, Tabasso G, Cinanni R, et al.. The surgical treatment of thoracolumbar metastases. Chirurg Organi Mov 1998,83:159-166.

8. Boriani S, Weintein JN, Biagini R. Primary bone tumors of the spine: terminology and surgical staging. Spine 1997;22:1036-1044.

9. Goutallier D, Lewertowski JM. Treatment of metastases of thoracic and lumbar vertebrae with predominant corporeal involvement by osteotomy of the vertebral body and anterior approach with cement and screwed plate. Rev Chirurg Orthop Reparatr Appareil Mot 1992,78:319-332. 